\section{Possibilities and limitations of using Lemna minor, Hydrocharis morsus-ranae and Ceratophyllum demersum in removing metals with contaminated water}

\author{
Małgorzata GAŁCZYŃSKA ${ }^{\text {1) ABDEF } ₫}{ }^{\text {, Natalia MAŃKOWSKA }}{ }^{2) ~ B D E F}$, \\ Justyna MILKE ${ }^{3) \text { BDEF }}$, Marta BUŚKO ${ }^{4) ~ D E}$
}

\author{
1), 2), 3), 4) West Pomeranian University of Technology, Faculty of Environmental Management and Agriculture, Department of Chemistry, \\ Microbiology and Biotechnology of Environment, ul. Juliusza Słowackiego 17, 71-434, Szczecin, Poland \\ 1) orcid.org/0000-0002-0796-0528; e-mail: malgorzata.galczynska@zut.edu.pl \\ 2) orcid.org/0000-0003-4656-6918; e-mail: natalia.szczerbinska@zut.edu.pl \\ 3) orcid.org/0000-0002-3363-7732; e-mail: justyna.milke@zut.edu.pl \\ 4) orcid.org/0000-0002-8245-0851; e-mail: busko.marta@zut.edu.pl
}

For citation: Gałczyńska M., Mańkowska N., Milke J., Buśko M. 2019. Possibilities and limitations of using Lemna minor, Hydrocharis morsus-ranae and Ceratophyllum demersum in removing metals with contaminated water. Journal of Water and Land Development. No. 40 (I-III) p. 161-173. DOI: 10.2478/jwld-2019-0018.

\begin{abstract}
The paper presents the assessment of possibilities and limitations of the use of Lemna minor, Hydrocharis morsus-ranae and Ceratophyllum demersum in removing metals from contaminated waters. Synthetically discussed the role of these species in phytotechnology and their importance in the assessment of surface water status. The variability of concentration of selected metals in waters and the content of metals in the organs of the analysed plants are presented. Their advantages and disadvantages in removing metals from waters due to biological features have been characterized. Minimum and maximum efficiency of metal removal depending on the scale of water pollution was determined. It was found that analysed plants can be used for phytoremediation of metals from water, but the limitation of effectiveness of treatments is the toxicity of these metals to plants and the time of exposure. The highest removal efficiency can be obtained thanks to the use of sequences of single-species filtration systems.
\end{abstract}

Key words: phytoremediation, heavy metals, hyperaccumulator, metal removal efficiency, duckweed, European frogbit, hornwort

\section{INTRODUCTION}

Pollution of aquatic ecosystems has a negative effect on organisms occurring therein [GAŁCZYŃSKA, BUŚKO 2016]. Toxic substances (e.g. heavy metals, pesticide residues, polycyclic aromatic hydrocarbons, dioxins or pharmaceuticals) accumulated in tissues of fish, molluscs and crustaceans can constitute a threat to human health when ingested [MENCH et al. 2009; OUALI et al. 2018]. Currently, there are various technologies used for the purpose of purification of surface waters, urban, domestic and industrial wastewater as well as wastewater sludge. Among these, par- ticularly noteworthy are solutions based on the use of phytotechnology [BELLO et al. 2018; CZYŻYK 2003; OBARSKA-PEMPKOWIAK et al. 2015; SKRZYPIEC, GAJEWSKA 2017].

Phytotechnology is based on the application of plants which, using solar energy and their life potential, help to improve the sanitary conditions and environmental protection of aquatic ecosystems. Such plants are characterised by highly efficient biologic systems which uptake and metabolise nutrients and, due to metabolic conversion regulated by photosynthesis, other substances as well [BHUPINDER 2010; WesOŁOWSKI, BRYSIEWICZ 2014]. Phytotechnology is considered cost-effective and environmentally 
friendly technique of environment decontamination. However, high initial concentration of pollutants present in the growth habitat can be toxic to such plants and, consequently, inhibit or even prevent the growth of the plants. Moreover, out of vegetative season, plant development and the resulting remediation processes may not occur. Prior to removal of any polluted plant material, risk analysis of its further use or processing may be necessary [AKHTAR et al. 2017].

Phytoremediation is defined as a method of using higher plants for the purpose of purification of contaminated environment [GHOSH, SINGH 2005] and includes five distinct mechanisms (Tab. 1).

Table 1. Types of phytoremediation

\begin{tabular}{|l|l|}
\hline \multicolumn{1}{|c|}{ Type } & \multicolumn{1}{c|}{ Mechanism } \\
\hline Rhizofiltration & $\begin{array}{l}\text { plants are used to absorb, concentrate, and precipitate } \\
\text { contaminants from polluted aquatic environment by } \\
\text { their roots }\end{array}$ \\
\hline $\begin{array}{l}\text { Phytostabiliza- } \\
\text { tion }\end{array}$ & $\begin{array}{l}\text { stabilization of contaminated soils by sorption, precip- } \\
\text { itation, complexation, or metal valence reduction ra- } \\
\text { ther than the removal of contaminants }\end{array}$ \\
\hline Phytoextraction & $\begin{array}{l}\text { phytoaccumulation, process that plants absorb, concen- } \\
\text { trate, and precipitate the contaminants in the biomass }\end{array}$ \\
\hline $\begin{array}{l}\text { Phytovolatiliza- } \\
\text { tion }\end{array}$ & $\begin{array}{l}\text { plants extract certain contaminants in nearby roots and } \\
\text { then transpire them into the atmosphere }\end{array}$ \\
\hline $\begin{array}{l}\text { Phytotransfor- } \\
\text { mation }\end{array}$ & $\begin{array}{l}\text { phytodegradation, process that plants remove contam- } \\
\text { inants from environment by their metabolism }\end{array}$ \\
\hline
\end{tabular}

Source: own elaboration.

\section{SELECTED AQUATIC PLANTS USED FOR ASSESSING WATER STATUS}

Lemna minor, Hydrocharis morsus-ranae, Ceratophyllum demersum are widely used in many European countries for the purpose of ecological status assessment of standing and flowing waters (the macrophyte index - MI in Germany, the trophic index of macrophytes - TIM in Germany, the mean trophic rank - MTR in Great Britain, indice biologique macrophytiqueen riviére - IBMR in France, the ecological state macrophyte index - ESMI in Poland, macrophyte river index - MRI in Poland, macrophyte index scheme - MIS in Ireland) [SzOSZKIEWICZ et al. 2009]. Only two of them, duckweed and hornwort, prefer water with a high trophic level (the index number of these species in MIR is $L=2$, with $L$ taking values from 1 for advanced eutrophy to 10 for oligotrophy), and European frogbit level with average trophic level $(L=6)$. These plants differ in the uptake of metals from surface waters.

Ceratophyllum demersum is a biological indicator of water pollution with cadmium and lead [DOGAN et al. 2015; VAHDATIRAAD, KHARA 2012], Lemna minor also serves as an indicator of pollution with lead [PRASAD, FREITAS 2003]. In turn, Hydrocharis morsus-ranae is an indicator of an increased concentration of zinc, iron and mercury in water [POLECHOŃSKA, DAMBIEC 2014].

Tables 2-4 present data on metal concentration in waters in which Lemna minor, Hydrocharis morsus-ranae and Ceratophyllum demersum occurred and metal content in organs of the analysed plant species. The data shown present high tolerance of these plants to pollution of water with metals.
Table 2. Content of metals in water and tissues of Lemna minor

\begin{tabular}{|c|c|c|c|c|c|}
\hline \multirow{3}{*}{ Metal } & \multirow{3}{*}{$\begin{array}{c}\text { Water } \\
\left(\mathrm{mg} \cdot \mathrm{dm}^{-3}\right)\end{array}$} & \multicolumn{3}{|c|}{ Plant species (mg.kg ${ }^{-1}$ d.w.) } & \multirow{3}{*}{ Reference } \\
\hline & & \multirow{2}{*}{ whole plant } & \multicolumn{2}{|c|}{ part of plant } & \\
\hline & & & leaves & roots & \\
\hline \multirow{2}{*}{$\mathrm{Na}$} & $1.5 \pm 0.2$ & - & - & - & $\begin{array}{l}\text { SASMAZ et al. } \\
{[2016]}\end{array}$ \\
\hline & - & $1500 \pm 420$ & - & - & $\begin{array}{l}\text { SIKORA et al. } \\
{[2018]}\end{array}$ \\
\hline \multirow[b]{2}{*}{$\mathrm{Pb}$} & $13 \pm 0.9$ & $\begin{array}{cccccc}- & \end{array}$ & & & RAI [2009] \\
\hline & - & - & $4.44-7.98$ & $3.80-10.2$ & $\begin{array}{l}\text { KASTRATOVIĆ } \\
\text { et al. [2015] }\end{array}$ \\
\hline $\mathrm{Cu}$ & $0.003-0.013$ & - & $7.94-22.3$ & $12.4-33.1$ & $\begin{array}{l}\text { KASTRATOVIĆ } \\
\text { et al.[2015] }\end{array}$ \\
\hline \multirow{2}{*}{$\mathrm{Zn}$} & $0.9 \pm 0.1$ & - & - & - & $\begin{array}{l}\text { SASMAZ et al. } \\
{[2016]}\end{array}$ \\
\hline & - & - & $41.3-82.5$ & $59.9-115$ & $\begin{array}{l}\text { KASTRATOVIĆ } \\
\text { et al. }[2015]\end{array}$ \\
\hline $\mathrm{Mn}$ & $0.008-0.013$ & - & $713-2590$ & $1543-4747$ & $\begin{array}{l}\text { KASTRATOVIĆ } \\
\text { et al. [2015] }\end{array}$ \\
\hline Co & $0.24-0.84$ & - & - & 5.60 & $\begin{array}{l}\text { KASTRATOVIĆ } \\
\text { et al. }[2018]\end{array}$ \\
\hline $\mathrm{Fe}$ & $196 \pm 20$ & - & - & - & $\begin{array}{l}\text { SASMAZ et al. } \\
{[2016]}\end{array}$ \\
\hline $\mathrm{Ni}$ & $0.28-1.08$ & 14.760 & 0.82 & 0.82 & $\begin{array}{l}\text { KASTRATOVIĆ } \\
\text { et al. [2018] }\end{array}$ \\
\hline \multirow[b]{2}{*}{$\mathrm{Hg}$} & $1.8 \pm 0.1$ & - & - & - & RAI [2009] \\
\hline & - & $0.76 \pm 0.03$ & - & - & $\begin{array}{l}\text { VARGA et al. } \\
{[2013]}\end{array}$ \\
\hline $\mathrm{Cd}$ & $<\mathrm{LOD}$ & - & $0-0.05$ & $0-0.83$ & $\begin{array}{l}\text { KASTRATOVIĆ } \\
\text { et al. }[2015]\end{array}$ \\
\hline $\mathrm{Cr}$ & $<0.002-0.002$ & - & - & $0.79-3.08$ & \begin{tabular}{|l|} 
KASTRATOVIĆ \\
et al. $[2015]$
\end{tabular} \\
\hline $\mathrm{Al}$ & - & $0.67 \pm 0.047$ & - & - & $\begin{array}{l}\text { RADIĆ et al. } \\
\text { [2009] }\end{array}$ \\
\hline $\mathrm{Tl}$ & - & $26.06 \pm 1.785$ & - & - & $\begin{array}{l}\text { BABIĆ et al. } \\
\text { [2009] }\end{array}$ \\
\hline
\end{tabular}

Explanation: LOD $=$ limit of detection.

Source: own elaboration based on literature.

\section{ANALYSED AQUATIC PLANTS AND THEIR USE IN WATER PURIFICATION}

Apart from helophytes (e.g. Phragmites australis) also pleustophytes as well as elodeids - represented by the analysed plant species Lemna minor, Hydrocharis morsus-ranae, and Ceratophyllum demersum [CZYŻYK 2003; FOROUGHI et al. 2010; SCHOLZ, ANDERSON 2003; SZCZERBIŃSKA, GAŁCZYŃSKA 2016] are used for purification of wastewater. In comparison with terrestrial plants, aquatic plants show greater capacity for bioaccumulation of high quantities of toxic metals and biogenic compounds [PRATAS et al. 2012]. Such plants, regardless of whether they are free-floating [UYSAL, TANER 2009], submersed [LI et al. 2018] or emergent [BELlo et al. 2018], are known for their ability to remove heavy metals. Hyperaccumulators of heavy metals can be identified with the use of bioconcentration coefficient (the ratio of the concentration of metal in plant to its concentration in water) or evaluation of the capacity for accumulating these elements in plant tissues in high quantities in relation to the concentration of metals in soil or water [UCER et al. 2013]. Currently proposed threshold values in $\mathrm{mg} \cdot \mathrm{kg}^{-1}$ weight for selected elements, above which the plant obtains the hyperaccumulator status, is: $100 \mathrm{mg} \cdot \mathrm{kg}^{-1} \mathrm{Se}, \mathrm{Cd}$ and $\mathrm{Tl}, 300 \mathrm{mg} \cdot \mathrm{kg}^{-1} \mathrm{Cu}, \mathrm{Co}$, $\mathrm{Cr} ; 1000 \mathrm{mg} \cdot \mathrm{kg}^{-1} \mathrm{Ni}$ and $\mathrm{Pb} ; 3000 \mathrm{mg} \cdot \mathrm{kg}^{-1} \mathrm{Zn}$ and 10000 $\mathrm{mg} \cdot \mathrm{kg}^{-1} \mathrm{Mn}$ [VAN DER ENT et al. 2013]. 
Table 3. Content of metals in water and tissues of Hydrocharis morsus-ranae

\begin{tabular}{|c|c|c|c|c|c|c|}
\hline \multirow{3}{*}{ Metal } & \multirow{3}{*}{$\begin{array}{c}\text { Water } \\
\left(\mathrm{mg} \cdot \mathrm{dm}^{-3}\right)\end{array}$} & \multicolumn{4}{|c|}{ Plant species $\left(\mathrm{mg} \cdot \mathrm{kg}^{-1}\right.$ d.w. $)$} & \multirow{3}{*}{ Reference } \\
\hline & & \multirow{2}{*}{ whole plant } & \multicolumn{3}{|c|}{ part of plant } & \\
\hline & & & stem & leaves & roots & \\
\hline \multirow{4}{*}{$\mathrm{Na}$} & $1.3-24.8$ & - & - & - & - & SKWIERAWSKI, SKWIERAWSKA [2013] \\
\hline & $8.3-33.74$ & $1460-11140$ & - & - & - & GAŁCZYŃSKA, BEDNARZ [2012] \\
\hline & - & - & $6847-26113$ & - & $11479-32394$ & POLECHOŃSKA, SAMECKA-CYMERMAN [2015b] \\
\hline & - & 8245 & - & - & - & SZCZERBIŃSKA, GALCZYŃSKA [2016] \\
\hline \multirow{4}{*}{$\mathrm{Ca}$} & $12.2-65.2$ & - & - & - & - & SKWIERAWSKI, SKWIERAWSKA [2013] \\
\hline & $41.89-125.9$ & $1610-30990$ & - & - & - & GAŁCZYŃSKA, BEDNARZ [2012] \\
\hline & - & - & $9080-48870$ & - & $13916-64593$ & POLECHOŃSKA, SAMECKA-CYMERMAN [2015b] \\
\hline & - & 3528 & - & - & - & SZCZERBIŃSKA, GALCZYŃSKA [2016] \\
\hline \multirow{5}{*}{$\mathrm{Pb}$} & $0-0.032$ & - & - & - & - & SKWIERAWSKI, SKWIERAWSKA [2013] \\
\hline & $0-0.211$ & $0-67.18$ & - & - & - & GAŁCZYŃSKA, BEDNARZ [2012] \\
\hline & - & - & $0.04-31.9$ & - & $0.42-11.1$ & POLECHOŃSKA, SAMECKA-CYMERMAN [2015a] \\
\hline & - & 4.23 & - & - & - & SZCZERBIŃSKA, GAECZYŃSKA [2016] \\
\hline & 0.60 & 348.2 & - & - & - & GALCZYŃSKA [2012] \\
\hline \multirow{6}{*}{$\mathrm{Cu}$} & $0-0.003$ & - & - & - & - & SKWIERAWSKI, SKWIERAWSKA [2013] \\
\hline & $0-0.002$ & - & - & $0.01-20.6$ & - & POLECHOŃSKA, DAMBIEC [2014] \\
\hline & $0-0.190$ & $3.44-29.40$ & - & - & - & GAŁCZYŃSKA, BEDNARZ [2012] \\
\hline & - & - & $0.71-61.4$ & - & $0.77-9.49$ & POLECHOŃSKA, SAMECKA-CYMERMAN [2015a] \\
\hline & - & 35.7 & - & - & - & SZCZERBIŃSKA, GAECZYŃSKA [2016] \\
\hline & 0.12 & 90.9 & - & - & - & GALCZYŃSKA [2012] \\
\hline \multirow{6}{*}{$\mathrm{Zn}$} & $0.001-0.020$ & - & - & - & - & SKWIERAWSKI, SKWIERAWSKA [2013] \\
\hline & $0.0006-0.0042$ & - & - & $9.58-46.8$ & - & POLECHOŃSKA, DAMBIEC [2014] \\
\hline & $0-0.085$ & $0.48-2219$ & - & - & - & GAŁCZYŃSKA, BEDNARZ [2012] \\
\hline & - & - & $9.58-157.1$ & - & $30.4-246$ & POLECHOŃSKA, SAMECKA-CYMERMAN [2015a] \\
\hline & - & 279 & - & - & - & SZCZERBIŃSKA, GALCZYŃSKA [2016] \\
\hline & 2.4 & 1776 & - & - & - & GALCZYŃSKA [2012] \\
\hline \multirow{6}{*}{ Mn } & $0.011-0.403$ & - & - & - & - & SKWIERAWSKI, SKWIERAWSKA [2013] \\
\hline & $0-0.151$ & - & - & $120-6322$ & - & POLECHOŃSKA, DAMBIEC [2014] \\
\hline & $0.001-3.284$ & $1001-12490$ & - & - & - & GAŁCZYŃSKA, BEDNARZ [2012] \\
\hline & - & - & $120-27713$ & - & $2795-42557$ & POLECHOŃSKA, SAMECKA-CYMERMAN [2015a] \\
\hline & - & 921 & - & - & - & SZCZERBIŃSKA, GALCZYŃSKA [2016] \\
\hline & 1.2 & 823 & - & - & - & GAŁCZYŃSKA [2012] \\
\hline \multirow{6}{*}{$\mathrm{Fe}$} & $0.01-1.49$ & - & - & - & - & SKWIERAWSKI, SKWIERAWSKA [2013] \\
\hline & $0-0.827$ & - & - & $102-4798$ & - & POLECHOŃSKA, DAMBIEC [2014] \\
\hline & $0.007-4.032$ & $90-7890$ & - & - & - & GAŁCZYŃSKA, BEDNARZ [2012] \\
\hline & - & & $102-14722$ & - & $1859-14627$ & POLECHOŃSKA, SAMECKA-CYMERMAN [2015a] \\
\hline & - & 10508 & - & - & - & SZCZERBIŃSKA, GAŁCZYŃSKA [2016] \\
\hline & 2.4 & 5020 & - & - & - & GAŁCZYŃSKA [2012] \\
\hline Co & 0.0053 & 155 & - & - & - & POLECHOŃSKA, SAMECKA-CYMERMAN [2018] \\
\hline $\mathrm{Ni}$ & 0.0571 & 511 & - & - & - & POLECHOŃSKA, SAMECKA-CYMERMAN [2018] \\
\hline
\end{tabular}

Source: own elaboration based on literature.

Among numerous aquatic plants, Lemna minor proves to be a hyperaccumulator of lead, nickel, chromium, copper, cadmium and manganese [AL-KHAFAJI et al. 2017; AlvarAdo et al. 2008; MiRETZKY et al. 2006; PRASAD, FREITAS 2003; REZANIA et al. 2016; UYSAL, TANER 2010], whereas Cerathopyllum demersum serves as a hyperaccumulator of zinc, lead, copper, arsenic, chromium, iron and cobalt [XING et al. 2013]. The amount of accumulation of various metals by Hydrocharis morsus-ranae does not met the criteria for identifying the species as hyperaccumulator [UCER et al. 2013].

\section{ADVANTAGES AND DISADVANTAGES OF SELECTED AQUATIC PLANTS IN REMOVING METALS FROM AQUATIC ECOSYSTEMS DUE TO BIOLOGIC FEATURES}

Plants used as phytoremediators acc. to KOŹMIŃSKA et al. [2014] should present the following features:

1) fast vegetative growth rates,

2) high biomass production,

3) well-developed root system (mass, length and the number of root ramifications),

4) tolerance to high concentration of heavy metals in soil or low demand for nutrients, 
Table 4. Content of metals in water and tissues of Ceratophyllum demersum

\begin{tabular}{|c|c|c|c|c|c|}
\hline \multirow{3}{*}{$\stackrel{\bar{m}}{\sum^{\frac{\pi}{2}}}$} & \multirow{3}{*}{$\begin{array}{c}\text { Water } \\
\left(\mathrm{mg} \cdot \mathrm{dm}^{-3}\right)\end{array}$} & \multicolumn{3}{|c|}{ Plant species (mg $\cdot \mathrm{kg}^{-1}$ d.w.) } & \multirow{3}{*}{ Reference } \\
\hline & & \multirow{2}{*}{$\begin{array}{c}\text { whole } \\
\text { plant }\end{array}$} & \multicolumn{2}{|c|}{ part of plant } & \\
\hline & & & stem & leaves & \\
\hline \multirow[b]{2}{*}{$\mathrm{Na}$} & $24 \pm 1.0$ & - & - & - & MARKICH et al. [2006] \\
\hline & - & 1478 & - & - & $\begin{array}{l}\text { SZCZERBIŃSKA, } \\
\text { GAŁCZYŃSKA [2016] }\end{array}$ \\
\hline \multirow[b]{2}{*}{$\mathrm{Ca}$} & $4.8 \pm 0.4$ & - & - & - & MARKICH et al. [2006] \\
\hline & - & 6279 & - & - & \begin{tabular}{|l|} 
SZCZERBIŃSKA, \\
GALCZYŃSKA [2016]
\end{tabular} \\
\hline \multirow{6}{*}{$\mathrm{Pb}$} & $<$ LOD & & $\begin{array}{c}2.74- \\
12.7\end{array}$ & $3.18-16.8$ & $\begin{array}{l}\text { KASTRATOVIĆ et al. } \\
\text { [2014] }\end{array}$ \\
\hline & - & 44.80 & - & - & KREMS et al. [2013] \\
\hline & \multirow[t]{2}{*}{ - } & 53.11 & 55.58 & 50.64 & $\begin{array}{l}\text { VAHDATIRAAD, KHA- } \\
\text { RA [2012] }\end{array}$ \\
\hline & & 275 & - & - & WANG et al. [2014] \\
\hline & $0.62-1.19$ & $\begin{array}{l}3.9- \\
10.8\end{array}$ & - & - & AL-GHANEM [2010] \\
\hline & - & 4.88 & - & - & \begin{tabular}{|l|} 
SZCZERBIŃSKA, \\
GALCZYŃSKA [2016]
\end{tabular} \\
\hline \multirow{4}{*}{$\mathrm{Cu}$} & $\begin{array}{c}0.002- \\
0.014\end{array}$ & & $\begin{array}{l}6.48- \\
24.5\end{array}$ & $9.85-34.5$ & $\begin{array}{l}\text { KASTRATOVIĆ et al. } \\
{[2014]}\end{array}$ \\
\hline & - & 6.17 & - & - & KREMS et al. [2013] \\
\hline & $0.1-1.07$ & $70-128$ & - & - & \begin{tabular}{|l|} 
MARKICH et al. \\
[2006], AL-GHANEM \\
[2010]
\end{tabular} \\
\hline & - & 52.3 & - & - & \begin{tabular}{|l|} 
SZCZERBIŃSKA, \\
GAŁCZYŃSKA [2016]
\end{tabular} \\
\hline \multirow{4}{*}{$\mathrm{Zn}$} & $\begin{array}{c}0.002- \\
0.008 \\
\end{array}$ & - & $\begin{array}{c}16.7- \\
75.6 \\
\end{array}$ & $25.6-58.9$ & $\begin{array}{l}\text { KASTRATOVIĆ et al. } \\
\text { [2014] }\end{array}$ \\
\hline & $0.095-0.45$ & - & - & $13.98-160$ & $\begin{array}{l}\text { KREMS } \text { et al. [2013]; } \\
\text { AL-GHANEM [2010] }\end{array}$ \\
\hline & - & 255 & - & - & \begin{tabular}{|l|} 
SZCZERBIŃSKA, \\
GAŁCZYŃSKA [2016] \\
\end{tabular} \\
\hline & - & 114 & - & - & WANG et al. [2014] \\
\hline \multirow{4}{*}{$\mathrm{Mn}$} & $\begin{array}{c}0.005- \\
0.014 \\
\end{array}$ & - & $\begin{array}{l}351- \\
1189 \\
\end{array}$ & 539-1984 & $\begin{array}{l}\text { KASTRATOVIĆ et al. } \\
{[2014]}\end{array}$ \\
\hline & $\begin{array}{c}0.022- \\
0.069 \\
\end{array}$ & \begin{tabular}{|c|}
$2938-$ \\
4328 \\
\end{tabular} & - & - & AL-GHANEM [2010] \\
\hline & - & 1785 & - & - & \begin{tabular}{|l|} 
SZCZERBIŃSKA, \\
GAŁCZYŃSKA [2016]
\end{tabular} \\
\hline & - & 8004 & - & - & WANG et al. [2014] \\
\hline \multirow{4}{*}{$\mathrm{Cd}$} & - & 0.98 & - & - & WANG et al. [2014] \\
\hline & 0.1 & 41.9 & - & - & \multirow{3}{*}{ DOGAN et al. [2015] } \\
\hline & 1.0 & 230.5 & - & - & \\
\hline & 10 & 824.7 & - & - & \\
\hline $\mathrm{Ni}$ & - & 2662 & - & - & WANG et al. [2014] \\
\hline \multirow[t]{2}{*}{$\mathrm{Fe}$} & $0.022-70$ & $\begin{array}{c}4298- \\
5539\end{array}$ & - & - & $\begin{array}{l}\text { FOROUGHI } \text { et al. } \\
\text { [2010]; MARKICH et } \\
\text { al. [2006], } \\
\text { AL-GHANEM [2010] }\end{array}$ \\
\hline & - & 14159 & - & - & \begin{tabular}{|l|} 
SZCZERBIŃSKA, \\
GAŁCZYŃSKA [2016]
\end{tabular} \\
\hline As & - & 16 & - & 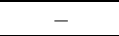 & \multirow{3}{*}{ WANG et al. [2014] } \\
\hline Co & - & 63 & - & - & \\
\hline $\mathrm{Cr}$ & - & 4242 & - & $\begin{array}{lllll}- & \end{array}$ & \\
\hline
\end{tabular}

Explanation: $\mathrm{LOD}=$ limit of detection.

Source: own elaboration based on literature.

5) ability to uptake and metabolise large quantities of toxic organic compounds,

6) limited capacity for transporting the accumulated pollutants to shoots,
7) ability to immobilise metals through precipitation, reduction or absorption by roots,

8) ability to accumulate high concentrations of metals in the aboveground parts.

The use of aquatic plants for the purpose of remediation involves the need to consider the ease of removing the plants in order to remove the accumulated pollutants from the object, as well as the necessity of controlling their population to avoid negative ecological effects (decreased biodiversity of the aquatic ecosystem due to excessive plant expansion).

Lemna minor is used mainly in rhizofiltration meeting the conditions listed above: 1, 2, 5, 6, 7. The advantages and disadvantages of this plant in terms of removing metal pollutants from aquatic ecosystems are presented in Table 5. This plant constitutes a very good bio-indicator with high ecological value as regards detecting and monitoring pollution with metals (Tab. 2). Tissue of Lemna minor is rich in protein as well as micro- and macro-elements which are a significant dietary ingredient for some animals (also of livestock such as cattle, swine or poultry), water birds (mainly ducks), herbivore fish, and at times even reptiles (e.g. water turtle) and insects such as some beetles [LENG et al. 1995].

Hydrocharis morsus-ranae. Taking into consideration the optimal features of plants used for purification of aquatic ecosystems from pollution [HANUS-FAJERSKA, KOŹMIŃSKA 2016], Hydrocharis morsus-ranae meets several conditions listed above: 1, 3, 4, 6, 7, 8 to be successfully used for removing metals mainly through processes of rhizofiltration and phytoextraction. The advantages and disadvantages of Hydrocharis morsus-ranae in removing metals from aquatic ecosystems in terms of physical traits and reproduction of this species are presented in Table 5.

Thick mats of Hydrocharis morsus-ranae inhibit light transmission to submersed plants, delay growth of algae as well as limit oxygen diffusion from the atmosphere. $\mathrm{Hy}$ drocharis morsus-ranae provides shelter and source of food for numerous animals: butterfly larvae, frogs and snails [CATLING et al. 2003].

This plant can develop in waters of various metal concentrations and may accumulate significant quantities of such metals (Tab. 5).

Ceratophyllum demersum is characterised by features required for species which are to be successfully used in phytoremediation, phytoaccumulation and phytoextraction: 1, 2, 4, 7 [KoŹMIŃSKA et al. 2014]. This hydrophyte demonstrated high potential for biomass production and vegetative propagation even in poor dietary conditions [ARAVIND et al. 2009] (Tab. 5). Additionally, Ceratophyllum demersum provides habitat for small animals (Stylaria lacustris, Caenis macrura, Corynoneura, Planorbis hortex et al.) and constitutes food source for some species of fish, snails, crustaceans, insects, water birds (e.g. ducks, rails) and rodents [BERNATOWICZ, Wolny 1974]. Ceratophyllum demersum can be used as a biofilter of pollutants, metals in particular. 
Table 5. The advantages and disadvantages of Lemna minor, Hydrocharis morsus-ranae and Ceratophyllum demersum in removing metals from aquatic ecosystems due to their construction and reproduction characteristics

\begin{tabular}{|c|c|c|c|}
\hline $\begin{array}{c}\text { Selected biological features } \\
\text { of the plant }\end{array}$ & Advantages & Disputable & Disadvantages \\
\hline \multicolumn{4}{|c|}{ Lemna minor } \\
\hline $\begin{array}{l}\text { Free-floating freshwater } \\
\text { aquatic plant }\end{array}$ & $\begin{array}{l}\text { - the ability to take mineral substances from the water, } \\
\text { has a high content of nitrogen and phosphorus } \\
\text { - pH of water from } 3.5 \text { to } 10 \\
\text { - a wide range of temperature tolerances }\end{array}$ & - & $\begin{array}{l}\text { generally does not participate in the } \\
\text { removal of metals and biogenic com- } \\
\text { pounds from bottom sediments }\end{array}$ \\
\hline $\begin{array}{l}\text { Plant with one, two, three or } \\
\text { four leaves each having a } \\
\text { single root hanging in the } \\
\text { water }\end{array}$ & $\begin{array}{l}\text { - accumulates more metals through completely im- } \\
\text { mersed in water } \\
\text { - removes shading }\end{array}$ & - & small biomass of single plant \\
\hline $\begin{array}{l}\text { It reproduces mainly vegeta- } \\
\text { tively by division }\end{array}$ & $\begin{array}{l}\text { - } \text { short breeding time }- \text { double number increase takes } \\
\text { place within } 1-4 \text { days } \\
\text { - trouble-free gathering from the water surface }\end{array}$ & $\begin{array}{l}\text { the length of the } \\
\text { growing season de- } \\
\text { termines the period of } \\
\text { use as a biofilter }\end{array}$ & $\begin{array}{l}\text { - in the development of large biomass } \\
\text { causes the cutting off of light, caus- } \\
\text { ing deterioration of growth condi- } \\
\text { tions for other vascular plants and } \\
\text { phytoplankton, which even leads to } \\
\text { their disappearance } \\
\text { - dense floating mats limit diffusion of } \\
\text { oxygen from the atmosphere to water }\end{array}$ \\
\hline \multicolumn{4}{|c|}{ Hydrocharis morsus-ranae } \\
\hline Free floating plant & $\begin{array}{l}\text { participates in the removal of metals and biogenic com- } \\
\text { pounds from the euphotic layer of surface waters }\end{array}$ & - & $\begin{array}{l}\text { in most cases does not participate in the } \\
\text { removal of metals and biogenic com- } \\
\text { pounds from bottom sediments }\end{array}$ \\
\hline $\begin{array}{l}\text { Cold-resistant up to }-20^{\circ} \mathrm{C} \text {, } \\
\text { perennial water plant }\end{array}$ & there is no need to obtain new plants every year & $\begin{array}{l}\text { will the next year's } \\
\text { new rosettes be more } \\
\text { resistant or more } \\
\text { sensitive to contami- } \\
\text { nants? }\end{array}$ & - \\
\hline Densely leafed rhizome & the ability to accumulate metal in leaves & - & short lifespan of leaves \\
\hline $\begin{array}{l}\text { Relatively short water roots } \\
\text { with long root hairs }\end{array}$ & the ability to accumulate metals in roots & - & - \\
\hline $\begin{array}{l}\text { Grows vegetatively through- } \\
\text { out the summer season }\end{array}$ & $\begin{array}{l}\text { biomass growth in the vegetative season leading to the } \\
\text { creation of a dense cluster of plants covering the surface } \\
\text { of small water reservoirs }\end{array}$ & $\begin{array}{l}\text { the length of the } \\
\text { vegetative season } \\
\text { determines the time } \\
\text { of biofiltration } \\
\end{array}$ & $\begin{array}{l}\text { dense plant mats limit the diffusion of } \\
\text { oxygen from the atmosphere }\end{array}$ \\
\hline \multicolumn{4}{|c|}{ Ceratophyllum demersum } \\
\hline Free floating plant & $\begin{array}{l}\text { - } \text { plant submerged } \\
\text { - the vulgar species produces winter shoots lying on } \\
\text { the bottom of the tank } \\
\text { - present in area aquatic plants and rush }\end{array}$ & $\begin{array}{l}\text { light intensity, expan- } \\
\text { sive species }\end{array}$ & $\begin{array}{l}\text { sensitive to reduction water level and } \\
\text { drying, does not freeze into the ice }\end{array}$ \\
\hline No roots & $\begin{array}{l}\text { - easy to obtain from the environment } \\
\text { - resistant to phytotoxicity of metals, e.g. Pb }\end{array}$ & - & $\begin{array}{l}\text { no possibility of collecting nutrients } \\
\text { and impurities from bottom sediments }\end{array}$ \\
\hline Stalk densely foliage & the possibility of metal accumulation in leaves & - & - \\
\hline Produces winter buds & there is no need to obtain new plants & - & - \\
\hline Vegetative reproduction & $\begin{array}{l}\text { - the possibility of pollination in water } \\
\text { - fast biomass growth - creates compact phytocoenoses } \\
\text { - the reproduction possible even with limited availabil- } \\
\text { ity of nutrients }\end{array}$ & $\begin{array}{l}\text { the length of the } \\
\text { growing season de- } \\
\text { termines the period of } \\
\text { use as a biofilter }\end{array}$ & - \\
\hline
\end{tabular}

Explanations: selected biological features of the plant for Lemna minor acc. to BERNATOWICZ and WOLNY [1974], and KŁOSOWSKI and KŁOSOWSKI [2001], for Hydrocharis morsus-ranae acc. to BUCZACKI [1997] and PODBIELKOWSKI and TOMASZEWICZ [1996] and for Ceratophyllum demersum acc. to BERNATOWICZ and WOLNY [1974] and PARNIAN et al. [2016].

Source: own elaboration.

\section{EFFICIENCY OF REMOVAL OF METALS FROM THE WATER ENVIRONMENT DEPENDING ON THE TIME OF PLANT EXPOSURE ON METAL CONTAMINATION AND METAL TOXICITY}

\section{EFFICIENCY OF METAL REMOVAL FROM AQUATIC ENVIRONMENT}

Analyses of aquatic plants with respect to determining the potential for removing metals from aquatic ecosystems were conducted for Lemna minor [AL-KHAFAJI et al. 2017; BASILE et al. 2012; BOKHARI et al. 2016; GOSWAMI et al.
2014; MiRANDA et al. 2014; SEKOMO et al. 2012; SzMIT et al. 2017; UYSAL 2013], Hydrocharis morsus-ranae [GAtCZYŃSKA 2012; POLECHOŃSKA, SAMECKA-CYMERMAN 2018] and Ceratophyllum demersum [CHEN et al. 2015; DuMAN, KocA 2014; KARA 2005; MATACHE 2013; REZANIA et al. 2016; UMEBESE, MOTAJO 2008].

Lemna minor. In biomonitoring of surface waters, Lemna minor is considered to be one of the main bioindicators of the level of pollution with selected metals. The conducted analyses of concentrations of, among others, heavy metals in biota, may provide much valuable information on pollutants introduced to aquatic ecosystems. The results of analyses confirmed usability of Lemna minor as a biomoni- 
tor of point sources of aquatic ecosystem pollution with, among others, lead and nickel [SZMIT et al. 2017].

GOSWAMI et al. [2014] showed that Common duckweed indeed has the potential for removing arsenic from aquatic ecosystems. The maximum removal of more than $70 \%$ of arsenic was reached with initial concentration of arsenic on the $0.5 \mathrm{mg} \cdot \mathrm{dm}^{-3} 15$ day of the experimental period lasting 22 days.

In a hydroponic experiment, BOKHARI et al. [2016] assessed the phytoremediation potential of Common duckweed in relation to elements $\mathrm{Cd}, \mathrm{Cu}, \mathrm{Pb}$ and Ni. Concentration of heavy metals in water and soil samples was analysed following 3,10,17, 24 and 31 day. The comparison of results in terms of efficiency of removal, metal uptake and bioconcentration coefficient confirmed accumulation of heavy metals in the plant and subsequent decrease in concentration determined in wastewater. For all metals, determined efficiency of removal was greater than $80 \%$, and the maximum removal for nickel was $99 \%$ for industrial wastewater.

In an experiment, AL-KHAFAJI et al. [2017] showed that mean efficiency of $\mathrm{Cd}, \mathrm{Cr}, \mathrm{Ni}$ and $\mathrm{Pb}$ removal for Lemna minor was $44.93 \%, 32.26 \%, 74.48 \%$ and $79.10 \%$, respectively, whereas SEKOMO et al. [2012] evidenced that regardless of metal accumulation rate, $\mathrm{Cr}$ removal coefficient in a pond overgrown with Common duckweed was 94\%. The elements such as $\mathrm{Pb}, \mathrm{Cd}$ and $\mathrm{Cu}$ were removed with the following efficiency: $36 \%, 33 \%$ and $27 \%$.

UYSAL [2013] demonstrated that Lemna minor has the ability to remove $\mathrm{Cr}(\mathrm{VI})$ ions from wastewater in a hydrophyte system. The following factors were identified: growth rate, chlorophyll content and ratio of dry or fresh weight of the plant to measurement of chromium toxicity. It was also found that chromium was successfully removed from water, and the greatest decrease was observed during the first 24 hours of the experiment (approx. 65-99\% of chromium added to medium with Lemna minor). Chromium removal efficiency was within the range of $41-66 \%$ in the first 7 days. During the study (21 days) Lemna minor demonstrated removal efficiencies of $40.8 \%, 48.5 \%$, $29.0 \%, 26.0 \%$ and $21.8 \%$ of added chromium ions, respectively in concentrations of $0.5,1.0,2.0,4.0$ and $5.0 \mathrm{mg} \cdot \mathrm{dm}^{-3}$.

MIRANDA et al. [2014] proved that among the analysed aquatic plants, Common duckweed is characterised by the highest efficiency of capturing most of heavy metals in- cluding almost complete i.e. $99 \%$ removal of $\mathrm{Cu}$ and $87 \%$ uptake of $\mathrm{Co}$. Concentrations $\mathrm{Ni}, \mathrm{Zn}, \mathrm{Fe}$ and $\mathrm{Cd}$ were reduced with lower efficiency $(61 \%, 58 \%, 43.4 \%$ and $57 \%$, respectively).

BASILE et al. [2012] observed that the highest efficiency of $\mathrm{Cd}$ removal was reached as early as after 7 hours of incubation and amounted to $95 \%$, whereas removal efficiency of $\mathrm{Pb}$ reached its maximum following 8 hours, i.e. $93 \%$. For $\mathrm{Cu}$ the maximum removal efficiency was recorded after 24 hours, i.e. $86.5 \%$, and in the case of $\mathrm{Zn}$ the efficiency was $63.5 \%$. KHELLAF and ZERDAOUI [2009] observed that metals such as $\mathrm{Cu}$ and $\mathrm{Cd}$ may cause visible damage to Common duckweed. Chlorosis was observed as well as separation of leaves from the root. With low concentration $\left(0.5 \mathrm{mg} \cdot \mathrm{dm}^{-3}\right)$ of $\mathrm{Cu}$, after 24 hours necrosis was observed. Cd inhibited the growth of Common duckweed at all concentrations selected for this analysis, $0.5 \mathrm{mg} \cdot \mathrm{dm}^{-3}$ concentration in medium resulted in visible damage a day after treatment, whereas at concentrations to $0.4 \mathrm{mg} \cdot \mathrm{dm}^{-3}$, there was a decrease in growth rate, colony separation and change in the colour of the leaves. Therefore, $\mathrm{Zn}$ was clearly less toxic element for Common duckweed as the manifestation of toxicity (slight discolouration and leaves separation) was observed only with $18 \mathrm{mg} \cdot \mathrm{dm}^{-3} \mathrm{Zn}$ and at higher concentrations.

Hou et al. [2007] noticed that $\mathrm{Cd}$, even at low concentrations $-0.05 \mathrm{mg} \cdot \mathrm{dm}^{-3}$, demonstrates toxicity through a decrease in photosynthetic pigment content in Lemna minor. The minimum and maximum removal efficiency of selected metals at various starting concentrations of this metal from the aquatic environment by Lemna minor were collected and shown in Figure 1a.

Hydrocharis morsus-ranae. GAŁCZYŃSKA [2012] conducted studies in the period of 3 and 6 weeks on the reaction of $H$. morsus-ranae to five metal solutions: $\mathrm{Pb}-$ $0.6, \mathrm{Zn}-2.4, \mathrm{Cu}-0.12, \mathrm{Mn}-1.2$ and $\mathrm{Fe}-2.4\left(\mathrm{mg} \cdot \mathrm{dm}^{-3}\right)$. The highest content of the discussed metals in frogbit was determined in aquatic environment without sludge and amounted to $348.2 \mathrm{mg} \cdot \mathrm{kg}^{-1} \mathrm{~d}$.w., for lead, $90.9 \mathrm{mg} \cdot \mathrm{kg}^{-1}$ d.w., for copper, $1776 \mathrm{mg} \cdot \mathrm{kg}^{-1} \mathrm{~d} . \mathrm{w}$., for zinc and 802 $\mathrm{mg} \cdot \mathrm{kg}^{-1} \mathrm{~d}$.w., for manganese. In the case of iron, the highest content of this metal, which amounted to $5020 \mathrm{mg} \cdot \mathrm{kg}^{-1}$ d.w., was found in the plant grown in a system with sludge. Pollution of water with salts of zinc or manganese in the amount of 2.4 and $1.2 \mathrm{mg} \cdot \mathrm{kg}^{-1} \mathrm{~d} . \mathrm{w}$., respectively, resulted
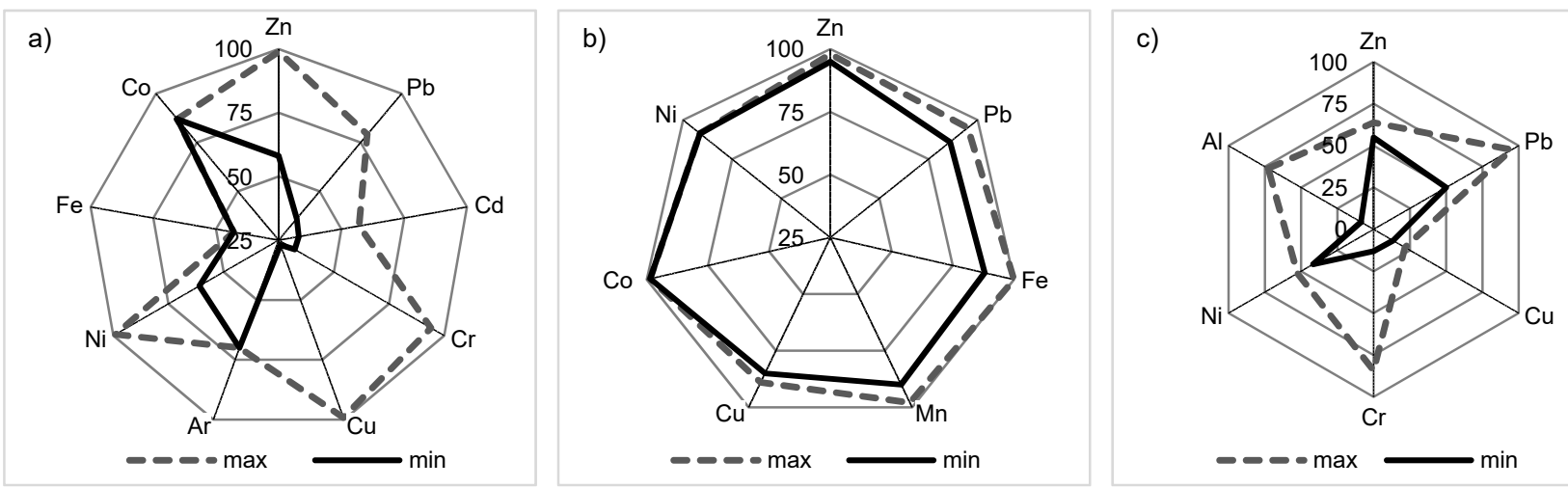

Fig. 1. Effectiveness of metal removal from the aquatic environment by: a) Lemna minor, b) Hydrocharis morsus-ranae, c) Ceratophyllum demersum; source: own study 
in a decrease of frogbit biomass production. In aquatic ecosystem with sludge, mean value of uptake efficiency coefficient - Eu (difference between metal content in dry weight of polluted plants and the content of metal in dry weight of plants in a control specimen divided by the introduced dosage of metal) for five metals was: $95 \%\left(E u_{\mathrm{Fe}}\right.$ $=105 \%, E u_{\mathrm{Zn}}=98 \%, E u_{\mathrm{Pb}}=95 \%, E u_{\mathrm{Mn}}=90 \%$ and $E u_{\mathrm{Cu}}=$ $89 \%$ ), and in environment without sludge the mean value was lower by only $6 \%\left(E u_{\mathrm{Mn}}=98 \%, E u_{\mathrm{Zn}}=95 \%, E u_{\mathrm{Fe}}=\right.$ $88 \%, E u_{\mathrm{Pb}}=86 \%$ and $\left.E u_{\mathrm{Cu}}=85 \%\right)$.

POLECHOŃSKA and SAMECKA-CYMERMAN [2018] described the reaction of $H$. morsus-ranae to water pollution with nickel and cobalt in the form of separate solutions and solutions of both metals with the following concentration of nickel $10.7,18.7,32.7,57.1,100\left(\mu \mathrm{g} \cdot \mathrm{dm}^{-3}\right)$, cobalt: $5.33,9.32,16.3,28.6,50.0\left(\mu \mathrm{g} \cdot \mathrm{dm}^{-3}\right)$, and $10.7 \mathrm{Ni}+5.33$ Co, 18.7 Ni + 9.32 Co, 32.7 Ni + 16.3 Co, 57.1 Ni + 28.6 $\mathrm{Co}, 100 \mathrm{Ni}+50.0 \mathrm{Co}\left(\mu \mathrm{g} \cdot \mathrm{dm}^{-3}\right)$. The content of $\mathrm{Co}$ and $\mathrm{Ni}$ in the plant increased with an increase in concentration of metals in the medium. In a solution of both metals, the presence of Ni disrupted accumulation of $\mathrm{Co}$ which resulted in lower Co content than that determined in plants grown in Co solutions. Notably high content of Co (till 155 $\mathrm{mg} \cdot \mathrm{kg}^{-1} \mathrm{~d}$.w.) and high efficiency of $\mathrm{Ni}$ uptake makes this species a very good accumulator of these metals. High content of both of these trace metals in plant tissue (till 511 $\mathrm{mg} \cdot \mathrm{kg}^{-1}$ d.w. Ni and $155 \mathrm{mg} \mathrm{kg}^{-1}$ d.w. Co) had no effect on plant growth which demonstrates tolerance of the plant to these toxic substances. The plant also showed an exquisite ability to remove Co (till $98.6 \%$ in solution with 5.33 $\left.\mu \mathrm{g} \cdot \mathrm{dm}^{-3} \mathrm{Co}\right)$ and $\mathrm{Ni}\left(91.4 \%\right.$ in solution $57.1 \mu \mathrm{g} \cdot \mathrm{dm}^{-3} \mathrm{Ni}$ and $28.6 \mu \mathrm{g} \cdot \mathrm{dm}^{-3} \mathrm{Co}$ ) from the medium.

The minimum and maximum removal efficiency of selected metals at various starting concentrations of this metal from the aquatic environment by Hydrocharis morsus-ranae were collected and shown in Figure $1 \mathrm{~b}$.

Ceratophyllum demersum. KARA [2005] observed that submerged species accumulate relatively high amount of heavy metals, as compared with emergent species. This is due to the physical traits of the species as because of its very thin epithelium the plants can remove heavy metals from water using its whole surface [REZANIA et al. 2016]. The analyses of biosorption conducted by, among others, KESHINKAN et al. [2004] and KREMS et al. [2013] showed that Ceratophyllum demersum can be used in $\mathrm{Pb}, \mathrm{Cu}$ and $\mathrm{Zn}$ biosorption and bioaccumulation. XING et al. [2013] indicate that Ceratophyllum demersum demonstrates a positive adaptive strategy in response to exposure to heavy metals in in situ studies. EL-KHATIB et al. [2014] described strong $\mathrm{Pb}$ accumulation potential of Ceratophyllum demersum in 7-day long study of this plant in hydroponic systems supplemented with various concentrations of $\mathrm{Pb}(25$, $\left.50,75 \mathrm{mg} \cdot \mathrm{dm}^{-3}\right)$. The highest accumulation values for Ceratophyllum demersum were observed for $\mathrm{Pb}$ (164.26 $\mathrm{mg} \cdot \mathrm{kg}^{-1}$ f.w.), the largest quantity of metal was accumulated following 1 day $\left(91.72 \mathrm{mg} \cdot \mathrm{kg}^{-1}\right)$. After 7 days, with 75 $\mathrm{mg} \cdot \mathrm{dm}^{-3}$, there was a significant decrease in the amount of photosynthetic pigment and occurrence of morphological symptoms such as chlorosis and leaves fragmentation. EL-KHATIB et al. [2014], DUMAN and KocA [2014], EL-
-KHATIB et al. [2014], and MiSHRA et al. [2006] showed that this plant is characterised by strong tolerance to lead and chromium following 7 days of exposition.

DUMAN and KOCA [2014] conducted an experiment to determine the way in which $\mathrm{Cr}$ (III) and $\mathrm{Cr}$ (VI) may affect various physiological and biochemical parameters of a plant. Ceratophyllum demersum was exposed to $\mathrm{Cr}$ (III) and $\mathrm{Cr}(\mathrm{VI})$ at various concentrations $(0.05 ; 0.1 ; 0.3$ and 0.5 $\left.\mathrm{mg} \cdot \mathrm{dm}^{-3}\right)$ and different exposition time (1, 2, 4 and 7 days), wherein the following was analysed: $\mathrm{Cr}$ accumulation, relative growth rate $(R G R)$, malondialdehyde content (MDA), photosynthetic pigmentation, proline content and activity of antioxidant enzymes. In the case of application of $\mathrm{Cr}(\mathrm{III})$ and $\mathrm{Cr}(\mathrm{VI})$ it was found that concentration has a significant effect on all of the analysed parameters. However, exposition time showed no statistically significant effect on proline content with application of $\mathrm{Cr}$ (III), nor on MDA and protein with application of $\mathrm{Cr}$ (VI). It was found that the factor of $\mathrm{Cr}$ concentration had a synergistic effect on the changes in the content of $R G R$, electrical conductivity, protein and antioxidant enzymes both with application of $\mathrm{Cr}$ (III) and well as $\mathrm{Cr}$ (VI).

CHEN et al. [2015] conducted a hydroponic experiment to identify the features of lead bioaccumulation and tolerance of Ceratophyllum demersum to exposition to various concentrations of this metal $\left(1.04-16.58 \mathrm{mg} \cdot \mathrm{dm}^{-3}\right)$ lasting 7,14 and 21 days. $\mathrm{Pb}$ accumulation increased with an increase in concentration of this metal in the solution, to a maximum accumulation $4016.4 \mathrm{mg} \cdot \mathrm{kg}^{-1}$ f.w., which shows hiperaccumulation of this element by Ceratophyllum demersum. At $\mathrm{Pb}$ concentration $1.04 \mathrm{mg} \cdot \mathrm{dm}^{-3}$, accumulation showed an increase throughout the whole experiment, with a rapid increase on day 7 and 14 when the plants accumulated $50 \%$ and $92 \% \mathrm{~Pb}$, respectively. With concentration of this metal $2.07 \mathrm{mg} \cdot \mathrm{dm}^{-3}$, the plants accumulated the maximum quantity of lead on 14 day, however, on day 21 there was a significant decrease in $\mathrm{Pb}$ content. With an initial concentration of lead in water was 1.04 $\mathrm{mg} \cdot \mathrm{dm}^{-3}$, Ceratophyllum demersum removed $60 \%$ on day 21 , reaching its highest efficiency. Additionally, a reaction of the plant to the stress caused by lead concentration was observed, i.e. a change in protein content in plants and change in biomass increase. Levels of malondialdehyde showed a considerable increase at lead concentration below $4.14 \mathrm{mg} \cdot \mathrm{dm}^{-3}$, which additionally proves that this metal is toxic for plants. The results suggest that Ceratophyllum demersum has strong tolerance to a specific range of $\mathrm{Pb}$ concentration and it is speculated that $8.29 \mathrm{mg} \cdot \mathrm{dm}^{-3}$ is the tolerance threshold of this plant to $\mathrm{Pb}$ in water.

REZANIA et al. [2016] indicated that efficiency of heavy metals removal by Ceratophyllum demersum with respect to $\mathrm{Cr}$ amounted to $13.0-84.3 \%$, and for $\mathrm{Pb}$ from 92.0 to $95.0 \%$. KESHINKAN et al. [2004] conducted laboratory analyses on $\mathrm{Cu}, \mathrm{Zn}$ and $\mathrm{Pb}$ sorption by Ceratophyllum demersum using approx. $2 \mathrm{~g}$ of fresh weight of the plant and concentrations $2,4,8,16,32$ and $64 \mathrm{mg} \cdot \mathrm{dm}^{-3}$ of these meals in a time period of $120 \mathrm{~min}$. It was found that the maximum absorption capacity $\left(q_{\max }\right)$ for Ceratophyllum demersum was $6.17 \mathrm{mg} \cdot \mathrm{g}^{-1}$ for $\mathrm{Cu}$ (II), $13.98 \mathrm{mg} \cdot \mathrm{g}^{-1}$ for $\mathrm{Zn}$ (II), and $44.8 \mathrm{mg} \cdot \mathrm{g}^{-1}$ for $\mathrm{Pb}$. 
The laboratory experiment conducted by CHOROM et al. [2012] lasted 15 days and used concentrations of $\mathrm{Ni} 6$, 4,2 , and $1 \mathrm{mg} \cdot \mathrm{dm}^{-3}$. Efficiency of metal removal from water was $41.7 \%, 50.0 \%, 52.5 \%$ and $46 \%$, respectively. With lengthening of exposition time, there was an increase in $\mathrm{Ni}$ removal efficiency from the medium. With a slow rate of $\mathrm{Ni}$ removal from the medium, Ceratophyllum demersum showed biomass increase and possibility of greater $\mathrm{Ni}$ accumulation.

PARNIAN et al. [2016] cultivated Ceratophyllum demersum for 8 days in greenhouse conditions using medium modified with an increasing $\mathrm{Cd}$ and $\mathrm{Ni}(0,1,2,4$ and 6 $\left.\mathrm{mg} \cdot \mathrm{dm}^{-3}\right)$ dosage. The obtained results showed that an increase in heavy metals concentration in medium resulted in a decrease in the plant biomass. Efficiency of metal removal by Ceratophyllum demersum was $82.0 \%$ for $\mathrm{Cd}$ and $52.5 \%$ for Ni. UMEBESE and MOTAJO [2008] exposed Ceratophyllum demersum to toxic concentrations of $\mathrm{Al}$ ( 3 and $\left.9 \mathrm{mg} \cdot \mathrm{dm}^{-3}\right), \mathrm{Zn}\left(3\right.$ and $\left.9 \mathrm{mg} \cdot \mathrm{dm}^{-3}\right)$ and $\mathrm{Cu}(2.5$ and $7 \mathrm{mg} \cdot \mathrm{dm}^{-3}$ ) in a solution for 15 days. It was found that Ceratophyllum demersum has much higher tolerance to aluminium $\left(E u_{3}=72.8 \%\right.$ and $\left.E u_{9}=68.8 \%\right)$ than to zinc $\left(E u_{3}=63.7 \%\right.$ and $\left.E u_{9}=54.9 \%\right)$, whereas its tolerance to copper $\left(E u_{2.5}=21.6 \%\right.$ and $\left.E u_{7}=13.43 \%\right)$ was very low. Greater dose of aluminium brought about a significant increase in chlorophyll content in the first 6 days of the experiment, whereas other metals caused a considerable decrease in chlorophyll content.

The minimum and maximum removal efficiency of selected metals at various starting concentrations of this metal from the aquatic environment by Ceratophyllum demersum were collected and shown in Figure 1c.

\section{USE OF THE CAPABILITY OF REMOVAL OF METALS FROM WEDNESDAY WATER BY ANALYZED WATER PLANTS}

Plants differ in their potential for metal uptake depending on the concentration values of a given metal in water, exposition time and availability of biogenic compounds [CHEN et al. 2015; DUMAN, KOCA 2014; GAŁCZYŃSKA 2012; UYSAL 2013]. The amount of biomass as well as efficiency of metal uptake from water affects the usability of plant for the purpose of phytoremediation of water. High concentration of metals in water may result in limited plant development and growth [GAŁCZYŃSKA 2012; PARNIAN et al. 2016]. This is an unfavourable phenomenon due to a decrease in biomass and temporal decline of efficiency of metal uptake. Many researchers stress that finding an optimum exposition time of a plant to pollution has a significant effect on reaching the greatest effect on removing metals from aquatic environment [CHEN et al. 2015; GAŁCZYŃSKA 2012; GOSWAMI et al. 2014; UYSAL 2013]. Most often, short-term exposure to high concentrations of metals allows for obtaining high level of purification. Such a relationship for Lemna minor was determined by UYSAL [2013]. It was found that in a period of 7 days, the efficiency of chromium removal was within the range of $41-66 \%$, and following 21 days, regardless of metal concentration levels, the efficiency decreased (22-49\%). Additionally, GAŁCZYŃSKA [2012] observed that due to short time of leaves mortality in Hydrocharis morsusranae rosettes and high efficiency of metal uptake in the period of 3 weeks of plant exposure to metal both at lower (aquatic environment without sludge - 90\%, aquatic environment with sludge - 93\%) as well as higher (aquatic environment - 91\%, soil-water environment - 98\%) concentrations of nitrogen, phosphorus and potassium compounds, there is no need to lengthen the exposition time of plant to pollutants present in the environment. The same trend was observed by CHEN et al. [2015] with respect to lead concentration equal to $2.07 \mathrm{mg} \cdot \mathrm{dm}^{-3}$, where Ceratophyllum demersum accumulated the maximum lead quantity on the 14 day, however with a considerable decrease in $\mathrm{Pb}$ on the 21 day of the experiment. In turn, according to CHOROM et al. [2012], following application of $2 \mathrm{mg} \mathrm{dm}^{-3} \mathrm{Ni}$, after 15 days, Ceratophyllum demersum showed the highest metal removal efficiency (52.5\%) which was additionally accompanied by an increase in biomass.

Taking into consideration the possibility for development of the analysed plants in environment polluted with metals, the rank of their applicability due to demonstrated tolerance to metal concentration and uptake efficiency was determined (Fig. 2).

The use of Lemna minor, Hydrocharis morsus-ranae and Ceratophyllum demersum for the purpose of purification of water polluted with metals can be achieved by immersing the plants located in special containers in water the containers would enable easy removal of the plants from the aquatic ecosystem under purification. When designing the containers, the need for protection of Lemna minor and Hydrocharis morsus-ranae from wind and water waves must be taken into account. The most favourable time for plant use is the vegetative season. For species such as Hydrocharis morsus-ranae and Lemna minor, this period lasts from mid-May to mid-September, and for Ceratophyllum demersum this period is slightly longer and lasts till mid-October. Following the period of no more than 2 weeks, the plants should be removed from water, dried and the resulting residue should be further utilised.

\section{SUMMARY}

On the grounds of the above-mentioned research by numerous authors, it was found that Lemna minor in the period of 21 days can remove from 22 to $41 \%$ chromium ions in concentration $0.5-5.0 \mathrm{mg} \cdot \mathrm{dm}^{-3}$ from the aquatic environment. In the case of arsenic, removal efficiency reached values of more than $70 \%$ at the concentration of $0.5 \mathrm{mg} \cdot \mathrm{dm}^{-3}$ following 15 days. In turn, mean $\mathrm{Cd}, \mathrm{Cu}$ and $\mathrm{Pb}$ removal efficiency from aquatic solutions $(0.038-0.054$ $\mathrm{mg} \cdot \mathrm{dm}^{-3} \mathrm{Cd} ; 0.0024-0.032 \mathrm{mg} \cdot \mathrm{dm}^{-3} \mathrm{Cu} ; 5.0-10.0 \mathrm{mg} \cdot \mathrm{dm}^{-3}$ $\mathrm{Pb})$ in the period of 31 days reached values over $81 \%$, and for $\mathrm{Ni}\left(2.5-5.0 \mathrm{mg} \cdot \mathrm{dm}^{-3}\right) 99 \%$. Hydrocharis morsus-ranae shows $95 \%$ potential for removing $\mathrm{Pb}\left(0.6 \mathrm{mg} \cdot \mathrm{dm}^{-3}\right), \mathrm{Cu}$ $\left(0.12 \mathrm{mg} \cdot \mathrm{dm}^{-3}\right), \mathrm{Zn}\left(2.4 \mathrm{mg} \cdot \mathrm{dm}^{-3}\right), \mathrm{Mn}\left(1.2 \mathrm{mg} \cdot \mathrm{dm}^{-3}\right), \mathrm{Fe}$ $\left(2.4 \mathrm{mg} \cdot \mathrm{dm}^{-3}\right)$ from aquatic environment in the period of 14 days, and Co $\left(0.005-0.050 \mathrm{mg} \cdot \mathrm{dm}^{-3}\right)$ and $\mathrm{Ni}(0.011-$ $0.100 \mathrm{mg} \cdot \mathrm{dm}^{-3}$ ) in the period of 7 days. Ceratophyllum demersum demonstrated the potential for metal removal in the period of 15 days from $73 \%$ to $95 \% \mathrm{~Pb}\left(1 \mathrm{mg} \cdot \mathrm{dm}^{-3}\right), \mathrm{Cr}$ 
a)

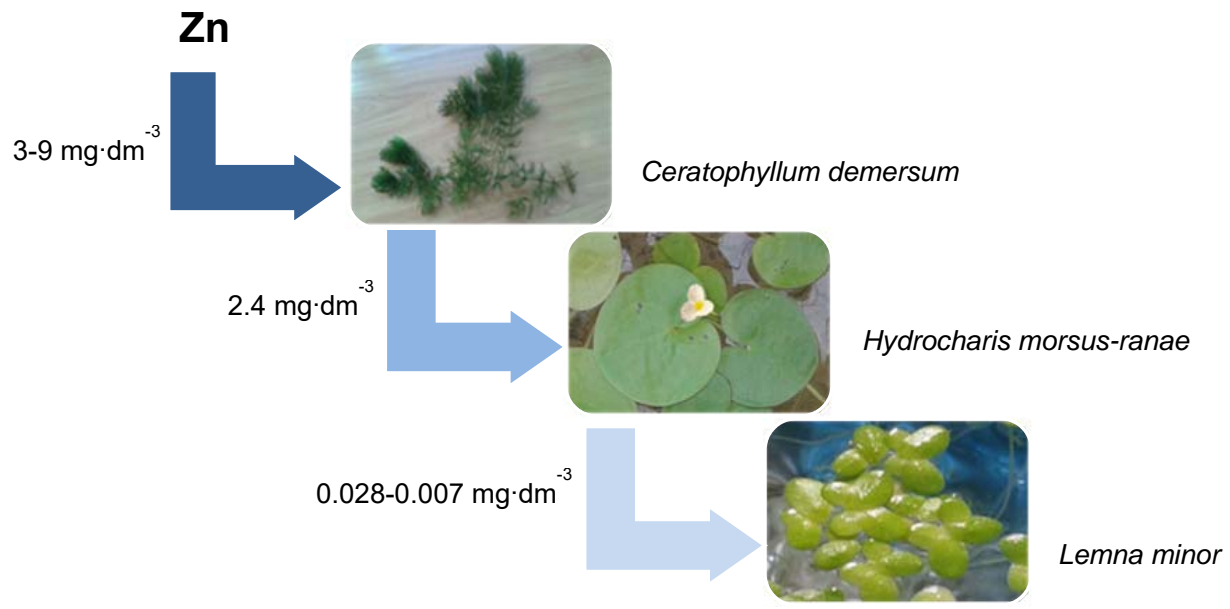

b)

$\mathrm{Pb}$

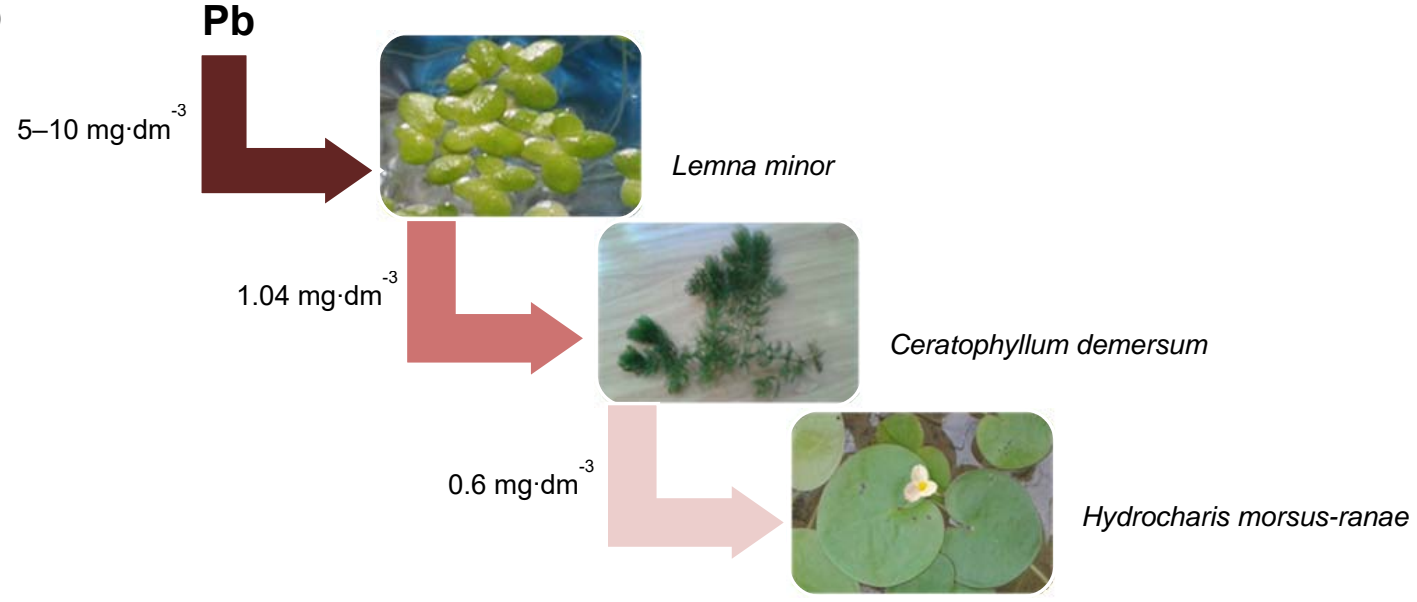

c)
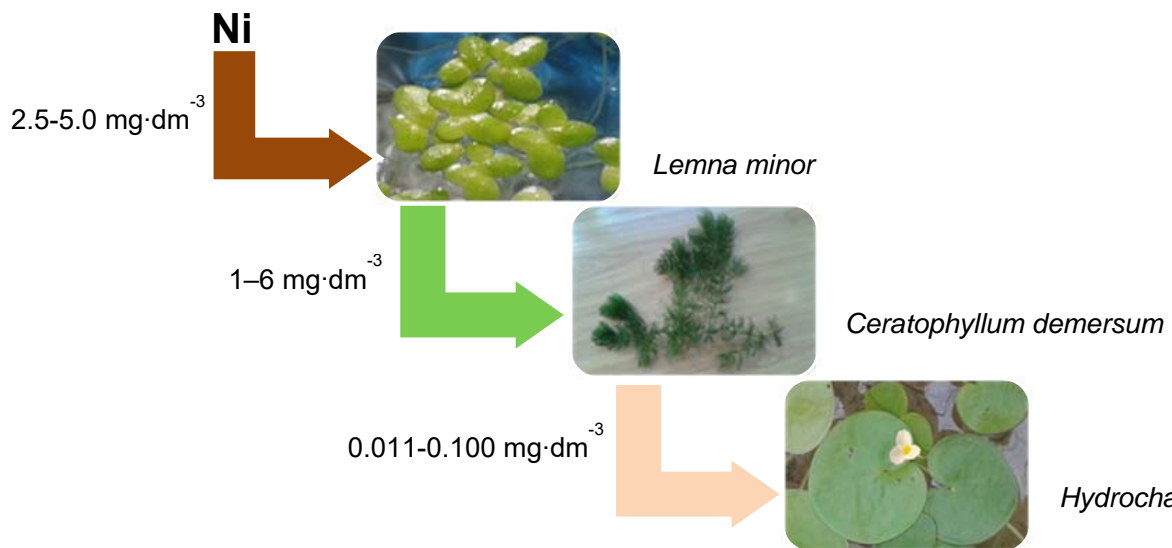

Hydrocharis morsus-ranae

d)

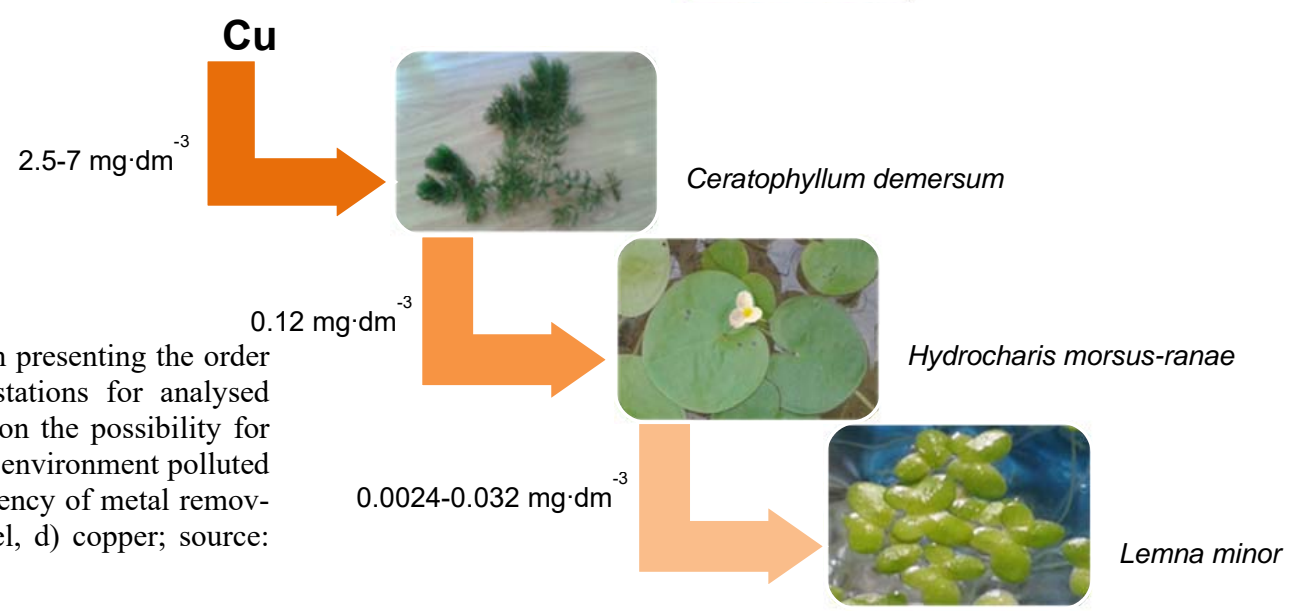

Fig. 2. The sequence diagram presenting the order of one-species biosorptive stations for analysed metal taking into consideration the possibility for plant development in aquatic environment polluted with a given metal and efficiency of metal removal: a) zinc, b), lead, c) nickel, d) copper; source: own study

\section{.}


$\left(2 \mathrm{mg} \cdot \mathrm{dm}^{-3}\right), \mathrm{Cd}\left(2 \mathrm{mg} \cdot \mathrm{dm}^{-3}\right)$ and $\mathrm{Al}\left(3 \mathrm{mg} \cdot \mathrm{dm}^{-3}\right)$ or from $21 \%$ to $63 \% \mathrm{Zn}\left(3 \mathrm{mg} \cdot \mathrm{dm}^{-3}\right)$, Ni $\left(2 \mathrm{mg} \cdot \mathrm{dm}^{-3}\right)$ and $\mathrm{Cu}$ $\left(3 \mathrm{mg} \cdot \mathrm{dm}^{-3}\right)$, with a decrease in metal removal efficiency following 21 days. Lemna minor, Ceratophyllum demersum and Hydrocharis morsus-ranae can be used for phytoremediation of toxic metals from aquatic ecosystems, however, toxicity of these metals and exposition time poses some limitation to efficacy of the plants' use. Geoclimatic conditions influence limitation of biomass increase, therefore there is a lack of sufficient amount of biomass of heavy metals hyperaccumulators to reach $100 \%$ efficiency of metal removal. The greatest efficiency of metal removal can be achieved using sequences of onespecies filtration systems. Providing that excess plants are removed from hydrophyte system (e.g. Lemna minor is removed several times in a year, Ceratophyllum demersum and Hydrocharis morsus-ranae 3 times), a decrease of metal pool in the system is permanent.

\section{REFERENCES}

Akhtar A.B.T., Yasar A., Ali R., Irfan R. 2017. Phytoremediation using aquatic macrophytes. In: Phytoremediation. No 5. Eds. A.A. Ansari, S.G. Sarvajeet, G. Ritu, R.L. Guy, L. Newman. 1st ed. Springer International Publishing p. 259-274.

AL-GHANEM W.M. 2010. Water and Ceratophyllum demersum analyses in Al-Jubail, East Saudi Arabia. Journal of the Arabian Aquaculture Society. No. 1(5) p. 35-43.

Al-KhafaJi M. S., AL-ANi F. H., IBRAHIM A. F. 2017. Removal of some heavy metals from industrial wastewater by Lemna minor. KSCE Journal of Civil Engineering. No. 22 (4) p. 10771082.

Alvarado S., Guedez M., Lue-Meru M.P., Nelson G., Alvaro A., Jesus A.C., GyULU Z. 2008. Arsenic removal from waters by bioremediation with the aquatic plants Water Hyacinth (Eichhornia crassipes) and Lesser Duckweed (Lemna minor). Bioresource Technology. No. 99 p. 8436-8440.

Aravind P., Prasad M.N.V., Malec P., Waloszek A., StrząKA K. 2009. Zinc protects Ceratophyllum demersum L. (freefloating hydrophyte) against reactive oxygen species induced by cadmium. Journal of Trace Elements in Medicine and Biology. No. 23 (1) p. 50-60.

Babić M., Radić S., Cvjetko P., Roje V., Pevalek-Kozlina B., Pavlica M. 2009. Antioxidative response of Lemna minor plants exposed to thallium(I)-acetate. Aquatic Botany. No. 91 p. $166-172$.

Basile A., Sorbo S., Conte B., Cobianchi R., Trinchella F., Capasso C., Carginale V. 2012. Toxicity, accumulation, and removal of heavy metals by three aquatic macrophytes. International Journal of Phytoremediation. No. 14(4) p. 374387.

Bello A.O., Tawabini B.S., Khalil A.B., Boland C.R., Saleh T.A. 2018. Phytoremediation of cadmium, lead and nickel contaminated water by Phragmites australis in hydroponic systems. Ecological Engineering. No. 120 p. 126-133. DOI 10.1016/j.ecoleng.2018.05.035.

BERNATOWICZ S., WolnY P. 1974. Botanika dla limnologów i rybaków [Botany for limnologists and fishermen]. 2nd ed. Warszawa. PWRiL pp. 449.

BHUPINDER D. 2010. Use of aquatic plants in removing heavy metals from wastewater. Journal of Environmental Engineering. No 2(1/2/3) p. 185-201.

BokHari S.H., AhMad I., Mahmood-Ul-Hassan M., MohamMAD A. 2016. Phytoremediation potential of Lemna minor L. for heavy metals. International Journal of Phytoremediation. No. $18: 1$ p. $25-32$.

BUCZACKI S. 1997. Rośliny wodne [Aquatic plants]. Warszawa. Elipsa. ISBN 8386893303 pp. 127.

Catling P.M., Mitrow G., Haber E., Posluszny U., Charlton W.A. 2003. The biology of Canadian weeds. 124. Hydrocharis morsus-ranae L. Canadian Journal of Plant Science. No. 83 p. 1001-1016.

CHEN M., ZHANG L.L., Li J., He X.J., CAI J.C. 2015. Bioaccumulation and tolerance characteristics of a submerged plant (Ceratophyllum demersum L.) exposed to toxic metal lead. Ecotoxicology and Environmental Safety. No 122 p. 313-321.

ChOROM M., PARnian A., JAAFARZADEH N. 2012. Nickel removal by the aquatic plant (Ceratopyllum demersum L.). International Journal of Environmental Science and Development. No. 3(4) p. 372-375.

CZYŻYK F. 2003. Badania efektywności pracy oczyszczalni gruntowo-roślinnych i wodno-roślinnych typu „Lemna” [Effectiveness of sewage treatment plants involving soil-vegetable and water vegetable "Lemna-type" system]. Ochrona Środowiska. No. 2 p. $57-60$.

Dogan M., AKGul H., InAN O.G., Zeren H. 2015. Determination of cadmium accumulation capabilities of aquatic macrophytes Ceratophyllum demersum, Bacopa monnieri and Rotala rotundifolia. Iranian Journal of Fisheries Sciences. No. 14(4) p. 1010-1017.

DuMAN F., Koca F.D. 2014. Single and combined effects of exposure concentration and duration on biological responses of Ceratophyllum demersum L. exposed to $\mathrm{Cr}$ species. International Journal of Phytoremediation. No. 16 p. 1192-1208.

El-KhatiB A.A, Hegazy A.K., AbO-El-Kassem A.M. 2014. Bioaccumulation potential and physiological responses of aquatic macrophytes to $\mathrm{Pb}$ pollution. International Journal of Phytoremediation. No. 16 p. 29-45.

Foroughi M., Najafi P., Toghiani A., Honarjoo N. 2010. Analysis of pollution removal from wastewater by Ceratophyllum demersum. African Journal of Biotechnology. No. 9(14) p. 2125-2128.

GAŁCZYŃSKA M. 2012. Reakcja przęstki pospolitej (Hippuris vulgaris L.) i żabiścieku pływającego (Hydrocharis morsusranae L.) na zanieczyszczenie wody wybranymi metalami ciężkimi i możliwości wykorzystania tych roślin w fitoremediacji wód [The response of Common Mare's Tail (Hippuris vulgaris L.) and Common Frogbit (Hydrocharis morsusranae L.) to the pollution of water with selected heavy metals, and the possibility to use this plant in phytoremediation of water]. Szczecin. Wydaw. ZUT w Szczecinie. ISBN 97883-7663-137-0 pp. 138.

GAŁCZYŃSKA M., BEDNARZ K. 2012. Influence of water contamination on the accumulation of some metals in Hydrocharis morsus-ranae L. Journal of Elementology. No. 17(1) p. 3141.

GAŁCZYŃSKA M., BUŚKO M. 2016. Stan zbiorników wodnych w Polsce oraz potencjalne i stosowane metody ich ochrony I rekultywacji [State of water reservoirs in Poland and potential and used methods of their protection and recultivation]. Wiadomości Melioracyjne i Łąkarskie. No. 3 p. 129-135.

GHOSH M., SingH S.P. 2005. A review on phytoremediation of heavy metals and utilization of its by products. Applied Ecology and Environmental Research. No. 3(1) p. 1-18.

Goswami C., Majumder A., Misra A.K., Bandyopadhyay K. 2014. Arsenic uptake by Lemna minor in hydroponic system. International Journal of Phytoremediation. No. 16 (12) p. 1221-1227.

HANUS-FAJERSKA E., KoźMIŃSKA A. 2016. The possibilities of water purification using phytofiltration methods: A review of recent progress. BioTechnologia. No. 97(4) p. 315-322. 
Hou W., Chen X., Song G., Wang Q., Chi Chang C. 2007. Effects of copper and cadmium on heavy metal polluted waterbody restoration by duckweed (Lemna minor). Plant Physiology and Biochemistry. No. 45 p. 62-69.

KARA Y. 2005. Bioaccumulation of $\mathrm{Cu}, \mathrm{Zn}$ and $\mathrm{Ni}$ from the waste water by Nastutium officianale. International Journal of Environmental Science and Technology. No. 2(1) p. 63-67.

Kastratović V., Bigović M., Jaćimović Ž., Kosović M., DuROVIĆ D., KRIVOKAPIĆ S. 2018. Levels and distribution of cobalt and nickel in the aquatic macrophytes found in Skadar Lake, Montenegro. Environmental Science and Pollution Research. No. 25(27) p. 26823-26830.

Kastratović V., Jaćimović Z., Durović D., Bigović M., KRIVOKAPIĆ S. 2015. Lemna minor L. as bioindicator of heavy metal pollution in Skadar Lake (Montenegro). Kragujevac Journal of Science. No. 37 p. 123-134.

Kastratović V., Krivokapić S., Bigović M., Đurović D., BLAGOJEVIĆ N. 2014. Bioaccumulation and translocation of heavy metals by Ceratophyllum demersum from Skadar Lake, Montenegro. Journal of the Serbian Chemical Society. No. 79(11) p. 1445-1460.

KeshinKan O., GoKsu M.Z., BasibuyuK M., Foster C.F. 2004. Heavy metal adsorption properties of a submerged aquatic plant (Ceratophyllum demersum). Bioresource Technology. No. 92(2) p. 197-200.

Khellaf N., ZerdaOUI M. 2009. Growth response of the duckweed Lemna minor to heavy metal pollution. Iranian Journal of Environmental Health Science and Engineering. No. 6(3) p. 161-166.

KŁOSOWSKi S., KŁosowsKi G. 2001. Rośliny wodne i bagienne [Water and marsh plants]. Warszawa. Ofic. Wydaw. Multico. ISBN 9788377633557 pp. 336.

KoźMiŃSKA A., HANus-FAJerSKA E., MuSZyŃSKA E. 2014. Możliwość oczyszczania środowiska wodnych metodą ryzofiltracji [Possibilities of water purification using the rhizofiltration method]. Woda-Środowisko-Obszary Wiejskie. T. 14. Z. 3 (47) p. 89-98.

Krems P., Rajfur M., WaCŁaweK M., KŁos A. 2013. The use of water plants in biomonitoring and phytoremediation of waters polluted with heavy metals. Ecological Chemistry and Engineering S. No. 20(2) p. 353-370.

Leng R.A., Stambolie J.H., Bell R.E. 1995. Duckweed a potential high protein feed resource for domestic animals and fish. Livestock Research for Rural Development. No. 7(1) p. 3651.

Li B., Gu B., YANG Z., ZhANG T. 2018. The role of submerged macrophytes in phytoremediation of arsenic from contaminated water: A case study on Vallisneria natans (Lour.) Hara. Ecotoxicology and Environmental Safety. No. 165 p. 224231. DOI 10.1016/j.ecoenv.2018.09.023.

MARKICH S.J., KING A.R., WiLSON S.P. 2006. Non-effect of water hardness on the accumulation and toxicity of copper in a freshwater macrophyte (Ceratophyllum demersum): How useful are hardness-modified copper guidelines for protecting freshwater biota? Chemosphere. No. 65(10) p. 1791-1800.

Matache M.L., Marin C., Rozylowicz L., Tudorache A. 2013. Plants accumulating heavy metals in the Danube River wetlands. Journal of Environmental Health Science and Engineering. No. 11(1): 39 .

Mench M., Schwitzguebel J., Schroeder P., Bert V., GAWRONSKI S., GUPTA S. 2009. Assessment of successful experiments and limitations of phytotechnologies: Contaminant uptake, detoxification and sequestration, and consequences for food safety. Environmental Science and Pollution Research. No. 16 p. $876-900$.

Miranda A.F., Muradov N., Gujar A., Stevenson T., Nugegoda D., Ball A.S., Mouradov A. 2014. Application of aquatic plants for the treatment of selenium-rich mining wastewater and production of renewable fuels and petrochemicals. Journal of Sustainable Bioenergy Systems. No. 4 p. $97-112$.

Miretzky P., Saralegui A., Cirelli A. F. 2006. Simultaneous heavy metal removal mechanism by dead macrophytes. Chemosphere. No. 62 p. 247-254.

Mishra S., Srivastava S., Tripathi R.D., Kumar R., Seth C.S., GUPTA D.K. 2006. Lead detoxification by coontail (Ceratophyllum demersum L.) involves induction of phytochelatins and antioxidant system in response to its accumulation. Chemosphere. No. 65 p. 1027-1039.

Obarska-PempKowiak H., KoŁecka K., BuchHoltz K., GaJewSKA M. 2015. Ekoinżynieria w zintegrowanym odwadnianiu i stabilizacji osadów ściekowych w systemach trzcinowych [Ecoengineering of integrated dewatering and stabilization of sewage sludge in reed systems]. Przemysł Chemiczny. No. 94(12) p. 2299-2303.

Ouali N., Belabed B.E., Zeghdoudi F., Rachedi M. 2018. Assessment of metallic contamination in sediment and mullet fish (Mugil cephalus Linnaeus, 1758) tissues from the East Algerian coast. Journal of Water and Land Development. No. 38 p. 115-126. DOI 10.2478/jwld-2018-0048.

Parnian A., Chorom M., JaAfarZadeh N., Dinarvand M. 2016. Use of two aquatic macrophytes for the removal of heavy metals from synthetic medium. Ecohydrology and Hydrobiology. No. 16(3) p. 194-200.

PODBIELKOWSKI Z., TOMASZEWICZ H. 1996. Zarys hydrobotaniki [The outline of hydrobotany]. Warszawa. PWN. ISBN 8301005661 pp. 530.

PoleChOŃSKA L., DAMBIEC M. 2014. Heavy metal accumulation in leaves of Hydrocharis morsus-ranae L. and biomonitoring applications. Civil and Environmental Engineering Reports. No. 12(1) p. 95-105.

Polechońska L., SAMECKA-CYMeRman A. 2015a. Bioaccumulation of macro- and trace elements by European frogbit ( $\mathrm{Hy}$ drocharis morsus-ranae L.) in relation to environmental pollution. Environmental Science and Pollution Research. No. 23(4) p. 3469-3480.

PolechońsKa L., SAmeCKA-Cymerman A. 2015b. The effect of environmental contamination on the decomposition of European frog-bit (Hydrocharis morsus-ranae L.) in natural conditions. Aquatic Botany. No. 127 p. 35-43.

POlEChOŃSKA L., SAMECKA-CYMERMAN A. 2018. Cobalt and nickel content in Hydrocharis morsus-ranae and their bioremoval from single- and binary solutions. Environmental Science and Pollution Research. Vol. 25. Iss. 32 p. 32044 35052. DOI 10.1007/s11356-018-3181-x.

Prasad M.N.V., Freitas H.M.D. 2003. Metal hyperaccumulation in plants - Biodiversity prospecting for phytoremediation technology. Electronic Journal of Biotechnology. No 93(1) p. 285-321.

Pratas J., Favas P. J. C., Paulo C., Rodrigues N., Prasad M. N.V. 2012. Uranium accumulation by aquatic plants from uranium-contaminated water in Central Portugal. International Journal of Phytoremediation. No 14 p. 221-234.

Radić S., Babić M., Skobić D., Roje V., Pevalek-Kozlina B. 2009. Ecotoxicological effects of aluminum and zinc on growth and antioxidants in Lemna minor L. Ecotoxicology and Environmental Safety. No 73(3) p. 336-342.

RAI P.K. 2009. Heavy metals in water, sediments and wetland plants in an aquatic ecosystem of tropical industrial region, India. Environmental Monitoring and Assessment. No. 158 p. 433-457.

ReZANia S., TAiB S.M., Din M.F.M., Dahalan F.A., KAMYaB H. 2016. Comprehensive review on phytotechnology: heavy metals removal by diverse aquatic plants species from 
wastewater. Journal of Hazardous Materials. No. 318 p. 587599.

Sasmaz A., Dogan I.M., Sasmaz M. 2016. Removal of Cr, Ni, and $\mathrm{Co}$ in the water of chromium mining areas by using Lemna gibba L. and Lemna minor L. Water and Environment Journal. No. 30(3-4) p. 235-242.

Scholz M., Anderson P. 2003. Case study: Design, operation and water quality management of a combined wet and dry pond system. European Water Management Online Journal. No. 95 p. $269-279$.

Sekomo C.B., Rousseau D.P, Saleh S.A., Lens P.N. 2012. Heavy metal removal in duckweed and algae ponds as a polishing step for textile wastewater treatment. Ecological Engineering. No. 44 p. 102-110.

Sikora J., Niemiec M., SzeląG-Sikora A. 2018. Evaluation of the chemical composition of raw common duckweed (Lemna minor L.) and pulp after methane fermentation. Journal of Elementology. No. 23(2) p. 685-695. DOI 10.5601/jelem. 2017.22.2.1444.

SkRZYPIEC K., GaJewSKA M.H. 2017. The use of constructed wetlands for the treatment of industrial wastewater. Journal of Water and Land Development. No. 34 p. 233-240. DOI 10.1515/jwld-2017-0058.

Skwierawski A., Skwierawska M. 2013. The role of Hydrocharitetum morsus-ranae in shaping the chemical composition of surface waters. Polish Journal of Environmental Studies. No. 22(6) p. 1825-1833.

SZCZERBIŃSKA N., GAŁCZYŃSKA M. 2016. Preliminary studies on the possibility of the use of single-species stands biosorption for municipal wastewater treatment. II International Conference "Human Ecology". 9-10.07.2016 Szczecin, Poland. Szczecin. Wydaw. ZUT p. 201-202.

SZMit K., MARCINIAK M., RAJfUR M. 2017. Lemna minor L. jako biomonitor punktowych źródeł zanieczyszczenia metalami ciężkimi ekosystemów wodnych. [Lemna minor L. as a biomonitor of point sources of aquatic ecosystems contamination with heavy metals]. Proceedings of ECOpole 2017. No. 1 p. 303-311.

SZOSZKIEWICZ K., ZBIERSKa J., StANisZeWSKi R., JusiK S. 2009. The variability of macrophyte metrics used in river monitoring. Oceanological and Hydrobiological Studies. No. 38 p. $117-126$.
UCer A., UyAnik A., Kutbay H.G. 2013. Removal of heavy metals using Myriophyllum verticillatum (whorl-leaf watermilfoil) in a hydroponic system. Ekoloji. No 22(87) p. 01-09.

UmeBese C. E., Motajo A.F. 2008. Accumulation, tolerance and impact of aluminium, copper and zinc on growth and nitrate reductase activity of Ceratophyllum demersum (Hornwort). Journal of Environmental Biology. No. 29(2) p. 197-200.

UYSAL Y. 2013. Removal of chromium ions from wastewater by duckweed, Lemna minor L. by using a pilot system with continuous flow. Journal of Hazardous Materials. No. 263 p. 486-492.

UYSAL Y., TANER F. 2009. Effect of pH, temperature, and lead concentration on the bioremoval of lead from water using Lemna minor. International Journal of Phytoremediation. No. 11 p. 591-608.

UYSAL Y., TANER F. 2010. Bioremoval of cadmium by Lemna minor in different aquatic conditions. Clean Soil Air Water. No. 38(4) p. 370-377.

VAHDATIRAAD L., KhaRA H. 2012. Heavy metals phytoremediation by aquatic plants (Hyrocotyle ranocloides, Ceratophyllum demersum) of Anzali lagoon. International Journal of Marine Science and Engineering. No. 2(4) p. 249-254.

VAN DER ENT A., BAKer A.J.M., ReEves R.D., Pollard A.J., SCHAT H. 2013. Hyperaccumulators of metal and metalloid trace elements: Facts and fiction. Plant Soil. No. 362 p. 319 334.

VARGA M., Horvatić J., ĆELIĆ A. 2013. Short term exposure of Lemna minor and Lemna gibba to mercury, cadmium and chromium. Central European Journal of Biology. No. 8(11) p. 1083-1093.

Xing W., Wu H., Hao B., Huang W., Liu G. 2013. Bioaccumulation of heavy metals by submerged macrophytes: looking for hyperaccumulators in eutrophic lakes Environmental Science and Technology. No. 47 p. 4695-4703.

WANG Z., YAo L., LiU G., LiU W. 2014. Heavy metals in water, sediments and submerged macrophytes in ponds around the Dianchi Lake, China. Ecotoxicology and Environmental Safety. No. 107 p. $200-206$.

WesOŁOWSKI P., BRYSIEWICZ A. 2014. Zdolność przybrzeżnej roślinności szuwarowej śródpolnych oczek wodnych do kumulacji makro- i mikroskładników [The ability to onshore rushes in mid-field ponds to accumulate macro and micronutrients]. Woda-Środowisko-Obszary Wiejskie. T. 14. Z. 1(45) p. 111-119.

\section{Małgorzata GAŁCZYŃSKA, Natalia MAŃKOWSKA, Justyna MILKE, Marta BUŚKO \\ Możliwości i ograniczenia stosowania Lemna minor, Hydrocharis morsus-ranae i Ceratophyllum demersum w usuwaniu metali z wód zanieczyszczonych}

\section{STRESZCZENIE}

W pracy przedstawiono ocenę możliwości i ograniczeń stosowania rzęsy drobnej, żabiścieku pływającego i rogatka sztywnego w usuwaniu metali z wód zanieczyszczonych. Syntetycznie omówiono rolę tych gatunków w fitotechnologii i ich znaczenie w ocenie stanu wód powierzchniowych. Przedstawiono zmienność stężenia wybranych metali w środowisku występowania roślin i zawartość metali w organach analizowanych roślin. Scharakteryzowano ich wady i zalety w usuwaniu metali z wód ze względu na cechy biologiczne. Określono minimalną i maksymalną efektywność usuwania metali w zależności od skali zanieczyszczenia wód. Ustalono, że wszystkie analizowane rośliny mogą być wykorzystywane do fitoremediacji metali toksycznych z ekosystemów wodnych, ale ograniczeniem skuteczności zabiegów jest toksyczność tych metali dla roślin i czas ekspozycji. Największą efektywność w usuwaniu metali można uzyskać dzięki zastosowaniu sekwencji jednogatunkowych układów filtracyjnych.

Słowa kluczowe: fitoremediacja, hiperakumulatory, metale ciężkie, rogatek sztywny, rzęsa drobna, skuteczność usuwania metali, żabiściek ptywajacy 